Falah: Jurnal Ekonomi Syariah

(p)ISSN: 2502-3918; (e)ISSN: 2502-7825

Vol 4, No 2 (Agustus 2019), pp.202-213

DOI: https://doi.org/10.22219/jes.v4i2.9877

\title{
Faktor-Faktor yang Mempengaruhi Pemilihan Model Bagi Hasil Pada Sektor Pertanian di Wilayah Karesidenan Madiun
}

\author{
Suyoto Arief \& Adib Susilo \\ Program Studi Ekonomi Islam, Fakultas Ekonomi dan Manajemen, \\ Universitas Darussalam Gontor \\ Email: suyotoarief1@gmail.com
}

\begin{abstract}
The purpose of this study was to determine whether socioeconomic factors, production factors, religiosity factors, and transparency factors influence the selection of agricultural production sharing models in the Residency of Madiun. This research is quantitative with multiple regression analysis. Based on the T-test, socioeconomic factors partially have a significant influence on the selection of agricultural production sharing models in the Madiun Residency of 3.701. Meanwhile, the factor of religiosity has a significant effect on the selection of agricultural production sharing models in the Madiun Residency with a significance level of 0.039 . Furthermore, the factor of production does not have a significant effect with a significance level of 0.778 . Finally, it is a factor that has a significant influence on the selection of revenue sharing models with a significance level of 0.008 . While based on ANOVA test results, the F count of 10.288 with a significance level of 0.000 is smaller than 0.05 , which means that socioeconomic, religiosity, production, and transparency factors simultaneously have an influence on the selection of revenue sharing models.
\end{abstract}

Keywords: Profit Sharing, Religiosity, Production, Transparency 


\begin{abstract}
ABSTRAK
Tujuan penelitian ini adalah untuk mengetahui apakah faktor sosial ekonomi, faktor produksi, faktor religiusitas dan faktor transparansi berpengaruh terhadap pemilihan model bagi hasil pertanian di Karesidenan Madiun. Penelitian ini adalah kuantitatif dengan analisis regresi berganda. Berdasarkan uji $\mathrm{T}$, faktor sosial ekonomi secara parsial memiliki pengaruh yang signifikan terhadap pemilihan model bagi hasil pertanian di Karasidenan Madiun sebesar 3,701. Sementara itu, faktor religiusitas berpengaruh signifikan terhadap pemilihan model bagi hasil pertanian di Karasidenan Madiun dengan tingkat signifikansi 0,039. Selanjutnya, faktor produksi tidak memiliki pengaruh yang signifikan dengan tigkat signifikansi sebesar 0,778. Terakhir, adalah faktor yang memiliki pengaruh signifikan terhadap pemilihan model bagi hasil dengan tingkat signifikansi sebesar 0,008. Sementara berdasarkan hasil uji anova, F hitung sebesar 10,288 dengan tingkat signifikansi 0.000 lebih kecil dari pada 0.05 yang berarti bahwa faktor sosial ekonomi, religiusitas, produksi, dan transparansi, secara simultan memiliki pengaruh terhadap pemilihan model bagi hasil.
\end{abstract}

Kata Kunci: Bagi Hasil, Religiusitas, Produksi, Transparansi.

\title{
1. Pendahuluan
}

Sektor pertanian merupakan salah satu sektor yang vital di dunia. Hal ini dapat dilihat dari fakta yang menunjukkan bahwa sektor pertanian memiliki kontribusi yang sangat signifikan terhadap pencapaian tujuan kedua dari program Sustainable Development Goals (SDG's) yaitu bebas dari kelaparan, mencapai ketahanan pangan, perbaikan nutrisi, serta mendorong budidaya pertanian yang berkelanjutan. Dalam konteks Indonesia, berdasarkan data Badan Pusat Statistik (BPS) pada Tabel 1.1 menjelaskan bahwa sektor pertanian memiliki peran penting yang tidak kalah dari sektor lainnya. Hal ini dikarenakan selama lima tahun terakhir (2014 - 2018) sektor pertanian merupakan penyumbang terbesar ketiga terhadap Produk Domestik Bruto (PDB) yang berperan sebagai pendorong pertumbuhan ekonomi nasional. Selain itu, pemerintah Indonesia juga sedang gencar melancarkan program-program yang berhubungan dengan peningkatan kapasitas produksi komoditas pertanian dalam upaya mendukung terwujudnya swasembada pangan di Indonesia (Dede, dkk, 2016). 
Tabel 1.1

Product Domestic Bruto (PDB)

Menurut Lapangan Usaha (dalam Triliun Rupiah)

\begin{tabular}{cccccc}
\hline $\begin{array}{c}\text { PDB Menurut Lapangan Usaha } \\
\text { (Harga Konstan 2010, Rp Triliun) }\end{array}$ & $\mathbf{2 0 1 4}$ & $\mathbf{2 0 1 5}$ & $\mathbf{2 0 1 6}$ & $\mathbf{2 0 1 7}$ & $\mathbf{2 0 1 8}$ \\
\hline Industri Pengolahan & 1,854 & 1,935 & 2,017 & 2,103 & 2,193 \\
\hline $\begin{array}{c}\text { Perdagangan Besar dan Eceran } \\
\text { Pertanian, Kehutanan, dan } \\
\text { Perikanan }\end{array}$ & 1,177 & 1,207 & 1,256 & 1,312 & 1,377 \\
\hline Konstruksi & 827 & 879 & 925 & 988 & 1,048 \\
\hline Pertambangan dan Penggalian & 794 & 767 & 775 & 780 & 797 \\
\hline Informasi dan Komunikasi & 384 & 422 & 459 & 503 & 539 \\
\hline Transportasi dan Pergudangan & 327 & 349 & 375 & 407 & 435 \\
\hline Jasa Keuangan dan Asuransi & 320 & 347 & 378 & 399 & 416 \\
\hline Administrasi Pemrintahan & 296 & 310 & 320 & 327 & 350 \\
\hline Penyediaan Akomodasi dan & 258 & 269 & 283 & 298 & 315 \\
\hline Makan & 256 & 267 & 280 & 290 & 300 \\
\hline Real Estate & 101 & 102 & 108 & 110 & 116 \\
\hline Pengadaan Listrik, Gas dan Air & 7,723 & 8,025 & 8,387 & 8,775 & 9,193 \\
\hline Jumlah Total & & &
\end{tabular}

Sumber: Badan Pusat Statistik (bps.go.id), 2018

Berdasarkan Tabel 1.2 di atas, data BPS selama lima tahun terakhir (2014 2018) dengan jelas menunjukkan bahwa provinsi Jawa Timur merupakan regional penyumbang PDRB terbesar kedua setelah DKI Jakarta. Lebih lanjut, Jawa Timur juga merupakan salah satu provinsi di Indonesia yang mempunyai lahan pertanian cukup luas. Berdasarkan data statistik luas lahan baku sawah untuk produksi beras saja mencapai 1.133.200 ha. di mana 862.376 ha. lahan irigasi dan 270.824 ha. lahan non-irigasi. Artinya Provinsi Jawa Timur pada produksi sektor pertanian memiliki kontribusi secara nasional (BPS, 2018).

Menurut Laporan Hasil Survei Pertanian Antar Sensus (SUTAS) tahun 2018 Provinsi Jawa Timur menunjukkan bahwa usaha pertanian yang ada didominasi oleh rumah tangga. Hal ini dapat dilihat berdasarkan besarnya jumlah rumah tangga usaha pertanian, di mana jumlah rumah tangga usaha pertanian di Jawa Timur tercatat sebanyak 5.163.979 rumah tangga, yang tersebar di 38 Kabupaten dan Kota di seluruh Jawa Timur (BPS Jatim, 2018).

Tabel 1.2

Produk Domestik Regional Bruto (PDRB) (dalam Triliun Rupiah)

\begin{tabular}{cccccc}
\hline PDRB (Rp Triliun) & 2014 & 2015 & 2016 & 2017 & 2018 \\
\hline DKI Jakarta & 1,373 & 1,455 & 1,540 & 1,635 & 1,736 \\
\hline
\end{tabular}




\begin{tabular}{cccccc}
\hline Jawa Timur & 1,263 & 1,331 & 1,406 & 1,482 & 1,564 \\
\hline Jawa Barat & 1,149 & 1,207 & 1,276 & 1,344 & 1,420 \\
\hline Jawa Tengah & 765 & 807 & 849 & 894 & 941 \\
\hline Sumatera Utara & 420 & 441 & 464 & 488 & 513 \\
\hline Riau & 448 & 449 & 459 & 471 & 482 \\
\hline Jumlah Total & 5,418 & 5,690 & 5,994 & 6,314 & 6,656
\end{tabular}

Sumber: Badan Pusat Statistik (bps.go.id), 2018

Berdasarkan data BPS tersebut, pegelolaan pertanian di Jawa Timur menyerap tenaga kerja yang sangat tinggi dan mampu saling mengungtungkan antar rumah tangga pertanian. Baik petani pengelola maupun petani pemilik lahan sehingga sistem bagi hasil menjadi salah satu solusi untuk meningkatkan keuntungan kedua belah pihak.

Bagi hasil pertanian merupakan transaksi pengelolaan tanah yang lazim di seluruh Indonesia, di mana pihak pemilik tanah atau penerima gadai tanah menyerahkan tanah pada petani dengan syarat harus menyerahkan bagian panen yang seimbang (Erviana, 2005). Keseimbangan ini diperlukan demi tercapainya kemakmuran dan kesejahteraan bagi kedua belah pihak. Tradisi perjanjian bagi hasil yang biasa dilakukan oleh masyarakat tersebut, pada umumnya dilakukan secara lisan dan atas dasar saling percaya antar sesama anggota masyarakat (Darhum \& Logawali, 2015).

Dalam Islam, sistem bagi hasil pertanian disebut dengan sistem Muzara'ah, Mukhabarah dan Musaqah. Muzara'ah merupakan sistem bagi hasil pertanian yang mengandung makna keadilan yang sempurna, dan mukhabarah adalah bentuk kerjasama antara pemilik tanah/sawah dan pengarap dengan perjanjian bahwa hasilnya dapat dibagi dua menurut kesepakatan bersama sedangkan biaya dan benihnya dari penggarap tanah. Di Jawa, khususnya Jawa Timur yang mempunyai sejarah Islam yang sudah mengakar, konsep Muzara'ah merupakan konsep bagi hasil pertanian yang syar'i. Serta memiliki unsur tolong menolong dan kerjasama yang sangat sesuai dengan pola masyarakat yang ada di Jawa Timur (Asnawi, 2005).

Bagi hasil pada sektor pertanian dengan prinsip syari'ah memiliki prospek yang baik pada masa depan. Hal tersebut disebabkan oleh beberapa faktor yaitu, karakteristik bagi hasil yang sudah berjalan di masyarakat Indonesia umumnya dan Jawa Timur khususnya sudah sesuai dengan karakteristik bagi hasil syari'ah, skema bagi hasil ini sudah dipraktikan secara luas di Indonesia. Luas cakupan usaha pertanian memungkinkan model bagi hasil syari'ah diterapkan, skema bagi hasil syari'ah yang berlandaskan pada ajaran agama secara emosional meningkatkan kepatuhan petani. Dan yang paling penting, usaha di sektor pertanian merupakan bisnis riil (Nugraha, 2016).

Pada penelitian ini faktor yang diduga memiliki pengaruh terhadap pemilihan tiga model bagi hasil pertanian Islam adalah faktor sosial ekonomi (Abdulsyani, 2007), faktor produksi (Sukirno, 2008), faktor religiusitas (ElMenouar, 2015), dan faktor transparansi (Wahyuni, 2013). Pada penelitian ini faktor sosial ekonomi yang diduga berpengaruh terhadap pemilihan model bagi hasil pertanian Islam adalah pendidikan (Ngadiyono, 1998), pendapatan (Marbun, 2003) dan kepemilikan lahan pertanian (asset) (Talundu, 2015). 
Sementara itu, faktor produksi yang diduga memiliki pengaruh terhadap pemilihan model bagi hasil adalah modal untuk memenuhi biaya produksi pengolahan lahan pertanian (Silvira, dkk., 2013), tenaga kerja yang digunakan selama mengolah lahan pertanian (Mahananto, 2009), dan penggunaan teknologi (Daryanto, 2003). Sedangkan faktor relgiusitas yang mempengaruhi pemilihan model bagi hasil dilihat dari dimensi relgius seseorang seperti keminan (Nashori, 2002), pengalaman religious (Nashori \& Mucharram, 2002), dan orthopraxis (ElMenouar, 2015).

Sementara itu, faktor transparansi dalam bagi hasil pertanian yang diduga berpengaruh adalah informatif yaitu pemberian arus informasi, berita, penjelasan mekanisme, prosedur, data, fakta, kepada stakeholders yang membutuhkan informasi secara jelas dan akurat (Iswahyudi, dkk, 2016), keterbukaan yaitu pemberian hak kepada setiap orang untuk memperoleh informasi dengan mengakses hal-hal yang perlu diketahui dan terkait dengan bagi hasil pertanian, dan menegaskan bahwa setiap informasi tersebut harus bersifat terbuka oleh petani penggarap (Asmani, 2012), dan pengungkapan yaitu pengungkapan kepada petani atas modal yang pemilik lahan gunakan dan sifat serta kualitas tanah yang dimiliki olehnya (Mardiasmo, 2004).

Berdasarkan latar belakang di atas maka penelitian ini bertujuan untuk mengetahui faktor-faktor yang berpengaruh terhadap bagi hasil pertanian di Karesidenan Madiun, dan apakah model bagi hasil pertanian di Karesidenan Madiun menerapkan model bagi hasil Islam.

\section{Tinjauan Pustaka}

\subsection{Teori Bagi Hasil}

Bagi hasil dalam aktivitas ekonomi adalah bentuk return atau perolehan, atau juga pengembalian dari kontrak kerja sama antara dua orang atau lebih yang melakukan akad dan besaran return bergantung pada hasil usaha yang dilakukan (Karim, 2004). Model bagi hasil pertanian dalam praktiknya menjadi pilihan antara petani penggarap dan petani pemilik tanah (pemilik lahan), karena praktik pengolahan lahan dengan model sewa terbukti dalam berbagai penelitian merugikan salah satu pihak, khususnya para petani yang lebih sering dirugikan karena besaran biaya tidak sebanding dengan keuntungan yang diraih (Braverman \& Srinivasan, 1981).

Praktik bagi hasil pertanian di Indonesia masih dikelola dengan berlandaskan pada asas kepercayaan antara pemilik lahan dengan petani penggarap. Pada praktik bagi hasil seperti ini, hak dan kewajiban masing-masing pihak yaitu pemilik tanah maupun penggarap ditetapkan atas dasar kesepakatan kedua belah pihak dan tidak pernah diatur secara tertulis. Besarnya bagian yang menjadi hak masing-masing pihak pun tidak ada keseragaman antara daerah yang satu dengan daerah yang lain. Sehingga bagi hasil pertanian dapat menggikuti ketentuan adat kebiasaan yang berlaku (Santoso, 2014).

Sejatinya perjanjian bagi hasil di Indonesia telah dirumuskan dalam UU Republik Indonesia nomer 2 tahun 1960 tentang perjanjian bagi hasil. UU ini 
dibentuk dengan tujuan mengatur perjanjian bagi hasil agar porsi bagi hasil tanah antara pemilik lahan dan penggarapnya dilakukakan dengan asas keadilan dan bertujuan untuk menegaskan hak dan kewajiban antara pemilik dan petani penggarap (Erviana, 2005).

Bagi hasil pertanian di Indonesia memiliki istilah tersendiri tergantung pada adat setempat. Istilah tersebut merujuk prosentase bagi hasil yang diperoleh untuk pemilik lahan dan petani penggarap. Beberapa contoh sistem bagi hasi pertanian berdasarkan adat adalah maro dan jejuron di pulau Jawa, nyakap di Lombok, mawaih di Aceh, memperduai di Sumatera Barat, melahi atau pebalokan terdapat di Tanah Karo, belah pinang di Toba, toyo di Minahasa, dan tesang di Sulawesi Selatan (Soekanto, 1986).

Sebagai contoh istilah penamaan bagi hasil pertanian di Jawa Tengah berdasarkan tiga model porsentase; (a) Pemilik tanah dan penggarapnya memperoleh bagian yang sama; (b) Pemilik tanah memperoleh $2 / 3$ bagian; (c) Pemilik tanah mendapat $1 / 5$ bagian untuk tanaman kacang (Erviana, 2005).

Sementara itu, model bagi hasil pertanian dalam Islam adalah muzara'ah, mukhabarah dan musaqah. Muzara'ah adalah kerjasama pengelolaan tanah dengan mendapat sebagian hasilnya. Sedangkan menurut istilah Fiqih ialah pemilik tanah memberi hak mengelola tanah kepada seorang petani dengan kesepakatan bagi hasil dari hasil tani atau semisalnya (Burhanuddin: 2010). Sedangkan mukhabarah ialah mengerjakan tanah (orang lain) seperti sawah atau ladang dengan imbalan sebagian hasilnya (seperdua, sepertiga atau seperempat) sedangkan biaya pengerjaan dan benihnya ditanggung orang yang mengerjakan.

Sementara itu, Secara bahasa musaqah diambil dari kata al-saqah, yaitu seseorang bekerja pada pohon tamar, anggur (mengurusnya). Atau pohon-pohon yang lainnya yang mendatangkan kemaslahatan dan mendapatkan bagian tertentu dari hasil yang diurus sebagai imbalan (Suhendi, 2008). Menurut Imam Syafi'i musaqah adalah seseorang mengupah orang lain untuk merawat kebun miliknya dengan pembagian hasil pertanian 50:50 atau 1/3 atau jumlahnya disesuaikan dengan kesepakatan kedua belah pihak (Syafi'i, 1961).

\section{Metode Penelitian}

Penelitian ini adalah kuantitatif menggunakan data primer, dan menggunakan analisis regresi berganda (Sugiyono, 2007). Data yang dikumpulkan dalam penelitian ini diperoleh dari Kabupaten Ngawi, Kabupaten Madiun, Kabupaten Magetan dan Kabupaten Ponorogo. 4 Kabupaten tersebut dipilih karena jumlah produksi pertanian untuk tanaman padi cukup luas. Berdasarkan data BPS produksi beras pada tahun 2018 untuk Kabupaten Ngawi sebanyak 432.673 ton, Madiun 244.153 ton, Magetan 181.181 ton dan Ponorogo sebanyak 216.778 ton (BPS, 2018). Data primer diambil dari petani penggarap lahan dan pemilik lahan dengan menggunakan kuesioner (Sugiyono, 2014). Sedangkan data sekunder berupa dokumen dari dinas pertanian terkait serta data statistik dari BPS yang 
merupakan data pendukung (Moleong, 1997). Pengumpulan data menggunakan 3 metode yaitu observasi, dokumentasi dan kuesioner (Piaw, 2006).

Adapun pengambilan sampel dalam penelitian ini menggunakan rumus Slovin (Sevilla, 1984). Rumus Slovin dapat dipakai untuk menentukan ukuran sampel, dengan memakai pendekatan distribusi normal dalam menduga proporsi populasi. Galat pendugaan (error) ditentukan oleh peneliti, yakni antara 5\% hingga $10 \%$.

\section{Analisis dan Pembahasan}

Berdasarkan Laporan Hasil Survei Pertanian Antar Sensus (SUTAS) tahun 2018 Provinsi Jawa Timur menunjukkan bahwa usaha pertanian yang ada didominasi oleh rumah tangga. Hal ini dapat dilihat berdasarkan besarnya jumlah rumah tangga usaha pertanian, di mana jumlah rumah tangga usaha pertanian di Jawa Timur tercatat sebanyak 5.163.979 rumah tangga, yang tersebar di 38 Kabupaten dan Kota di seluruh Jawa Timur. Sedangkan rata-rata luas lahan yang dikuasai petani di jawa timur dalam $\mathrm{m}^{2}$ pada tahun 2018 adalah $3531,26 \mathrm{~m}^{2}$.

Pada penelitian ini lokasi penelitian yang dipilih adalah 4 dari 5 kabupaten karasidenan madiun Sedangkan rata-rata lahan yang dikuasai petani untuk kabupaten Ponorogo seluas 3050,80 $\mathrm{m}^{2}$, kabuaten Magetan seluas 2872,24 $\mathrm{m}^{2}$, kabupaten Madiun seluas 3045,75 $\mathrm{m}^{2}$, dan kabupaten Ngawi seluas 3456,33 $\mathrm{m}^{2}$. Sementara itu jumlah rumah tangga pertanian di kabupaten Ponorogo 185.737 rumah tangga, Magetan 98.845 rumah tangga, Madiun 118.616 rumah tangga, dan Ngawi 170.875 rumah tangga.

Berdasarkan data dari BPS Jawa Timur tercatat bahwa Produksi beras pada tahun 2018 untuk Kabupaten Ponorogo adalah sebanyak 216.778 ton. Sedangkan untuk kabupaten Madiun sebanyak 244.153 ton. Sementara itu, Kabupaten Ngawi sebanyak 432.673 ton dan Kabupaten Magetan sebanyak 181.181 ton. Sedangkan untuk produksi padi pada tahun 2018 Ponorogo memproduksi sebanyak 377.367 ton. Sementara itu Madiun memproduksi padi sebanyak 425.023 ton. Sedangkan Ngawi sebanyak 753.199 ton dan Magetan sebanyak 315.400 ton. Grafik produksi padi pada 4 kabupaten di karesidenan Madiun dapat dilihat pada gambar 1.1 di bawah ini,

Gambar 1.1

Produksi Padi dan Beras dalam Ton

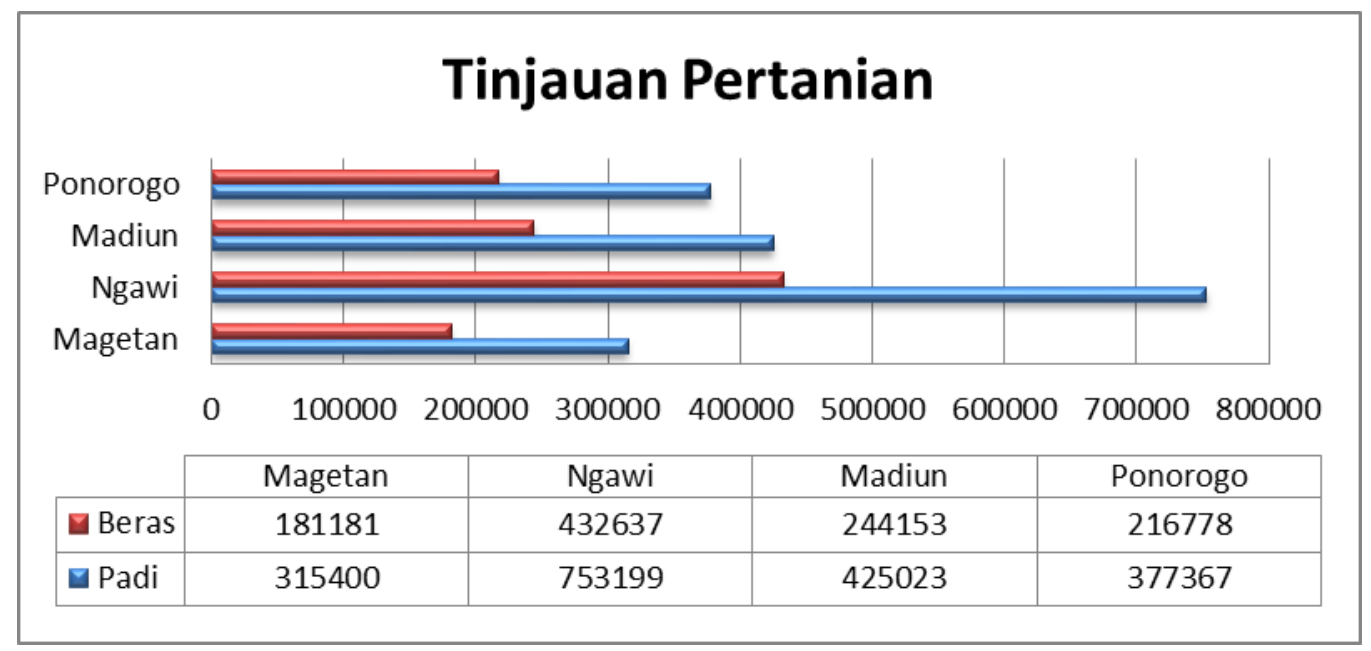

Vol. 4, No.2, Agustus 2019 


\subsection{Faktor-faktor yang Mempengaruhi Pemilihan Model Bagi Hasil}

Untuk melihat pengaruh variabel Faktor Sosial Ekonomi, Faktor Produksi, Faktor Religiusitas dan Faktor Transparansi terhadap variabel Pemilihan Model Bagi Hasil Pertanian, maka SPSS 20 digunakan untuk menganalisa data yang telah diperoleh melalui angket kuesioner. Adapun hasil analisis dapat dilihat pada table 1.3 di bawah ini:

Tabel 1.3

Tabel Uji Anova

ANOVA ${ }^{a}$

\begin{tabular}{ccccccc}
\hline \multirow{2}{*}{ Model } & $\begin{array}{c}\text { Sum of } \\
\text { Squares }\end{array}$ & df & $\begin{array}{c}\text { Mean } \\
\text { Square }\end{array}$ & F & Sig. \\
\hline \multirow{3}{*}{1} & Regression & 13.209 & 4 & 3.302 & 10.288 & $.000^{\mathrm{b}}$ \\
& Residual & 126.781 & 395 & .321 & & \\
& Total & 139.990 & 399 & & & \\
\hline & \multicolumn{2}{c}{ Sumber: Data diolah, 2019} & & &
\end{tabular}

a. Dependent Variable: Y (Pemilihan Model Bagi Hasil)

b. Predictors: (Constant), X4 (transparansi), X3 (Religiusitas), X1 (Faktor Sosial Ekonomi), X2

(Faktor Produksi)

Berdasarkan hasil uji anova, $\mathrm{F}$ hitung sebesar 10,288 dengan tingkat signifikansi 0.000 lebih kecil dari pada 0.05 sehingga dapat diambil kesimpulan bahwa Transparansi, Religiusitas, Faktor Sosial Ekonomi, dan Faktor Produksi secara simultan atau bersama-sama memiliki pengaruh terhadap pemilihan model bagi hasil. Oleh karena itu hipotesis $H_{l}$ yang diajukan didukung. Sementara itu secara parsial, pengaruh masing-masing variabel $\mathrm{X}$ terhadap $\mathrm{Y}$ dapat dilihat pada tabel di bawah ini:

Tabel 1.4

Tabel Koifisien Statistik

Coefficients $^{\mathbf{a}}$

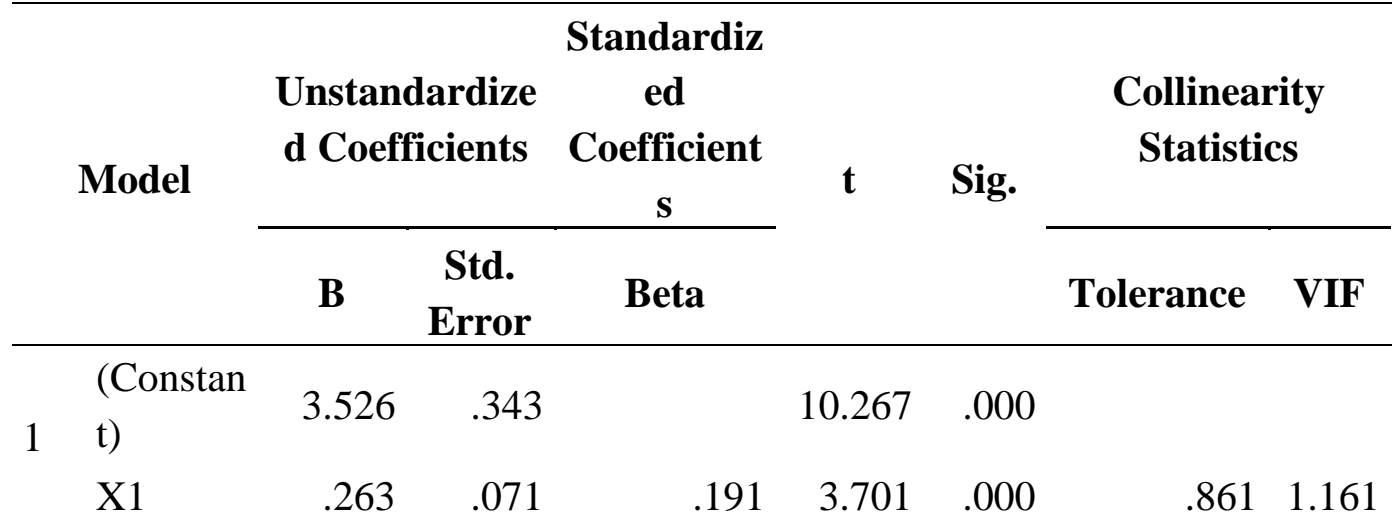

Falah: Jurnal Ekonomi Syariah 


\begin{tabular}{rrrrrrrr}
$\mathrm{X} 2$ & -.141 & .068 & -.156 & -2.069 & .039 & .406 & 2.466 \\
$\mathrm{X} 3$ & .020 & .072 & .016 & .282 & .778 & .755 & 1.325 \\
$\mathrm{X} 4$ & -.169 & .063 & -.191 & -2.680 & .008 & .449 & 2.227 \\
\hline
\end{tabular}

a. Dependent Variable: Y

Sumber: Data diolah, 2019

Berdasarkan koifisien tersebut, dapat diambil kesimpulan bahwa konstanta dalam penelitian ini adalah sebesar 3,526. Sedangkan nilai X1 atau Faktor Sosial Ekonomi adalah sebesar 0,263 yang artinya jika konstanta $\mathrm{Y}$ atau model bagi hasil berubah sebanyak 1, maka X1 atau Faktor Sosial Ekonomi akan berubah sebesar 0,263. Sedangkan nilai X2 atau Faktor Produksi adalah sebesar -0,141 yang artinya jika konstanta $\mathrm{Y}$ atau model bagi hasil berubah sebanyak 1 , maka X2 atau Faktor Produksi dapat berubah sebesar -0,141. Sedangkan nilai X3 atau Faktor Religiusitas adalah sebesar 0,020 yang artinya jika konstanta Y atau model bagi hasil berubah sebanyak 1, maka X3 atau Faktor Religiusitas dapat berubah sebesar 0,020. Terakhir, nilai X4 atau Faktor Transparansi adalah sebesar -0,169 yang artinya jika konstanta $\mathrm{Y}$ atau model bagi hasil berubah sebanyak 1, maka X4 atau Faktor Transparansi dapat berubah sebesar -0,169.

Berdasarkan uji T, T hitung untuk X1 adalah sebesar 3,701 dengan tingkat signifikansi sebesar 0,000 > dari pada 0,05 yang berarti Faktor Sosial Ekonomi secara parsial atau sendiri-sendiri memiliki pengaruh yang signifikan terhadap pemilihan model bagi hasil pertanian di Karasidenan Madiun yang artinya hipotesis yang diajukan didukung. Hal tersebut sejalan dengan penelitian yang dilakukan oleh Torar (2009) yang menyatakan bahwa faktor social ekonomi berpengaruh terhadap pemilihan model bagi hasil pertanian. Di Jawa Timur luas lahan cukup berpengaruh terhadap seseorang untuk memilih model bagi hasil yang saling mengungtungkan antara pemilik lahan dengan petani penggarap. Begitu pula faktor pendidikan atau pengetahuan petani tentang pengelolaan lahan, kualitas lahan serta penggunaan teknologi modern dapat mendorong pemlihan model bagi hasil pertanian yang saling mengungtungkan.

Sementara itu, T hitung untuk X2 adalah -2,069 dengan tingkat signifikansi 0,039 yang berarti Faktor Religiusitas secara parsial atau sendiri-sendiri berpengaruh signifikan terhadap pemilihan model bagi hasil pertanian di Karasidenan Madiun yang artinya hipotesis yang diajukan didukung. Sementara itu faktor religiusitas sebagai faktor pemilihan menentukan model bagi hasil pertanian yang dipilih oleh petani pemilik lahan dengan petani penggarap. Dalam peneltian ini petani memilih model bagi hasil adat. Hal tersebut karena walaupun religiustias memiliki pengaruh terhadap variable bagi hasil, tetapi koefisiennya adalah negatif. Sehingga semakin religius responden, maka model bagi hasil Islam tidak menjadi pilihan. Hal ini sesuai dengan penelitian yang dilakukan oleh Priyadi dan Siddiqie (2015) yang menyatakan bahwa pelaksanaan bagi hasil pertanian Islam atau muzara'ah belum menjadi pilihan utama petani. Sejalan dengan hal tersebut Nuramadany (2016) menyatakan bahwa pelaksanaan perjanjian bagi hasil pertanian lebih cendrung pada hukum adat atau kebiasaan yang telah ada di masyarakat daripada hukum Islam.

Selanjutnya, T hitung untuk X3 adalah 0,282 dengan tigkat signifikansi sebesar 0,778 yang artinya Faktor Produksi secara parsial atau sendiri-sendiri 
tidak memiliki pengaruh yang signifikan terhadap pemilihan model bagi hasil pertanian di Karasidenan Madiun. Hal tersebut mengindikasikan bahwa hipotesis yang diajukan ditolak. Hal tersebut mendukung penelitian yang telah dilakukan oleh Rondhi dan Adi (2018) yang menyatakan bahwa lahan dengan model sewa lebih produktif daripada dengan bagi hasil yang menguntungkan petani pengelola lahan. Faktor produksi yang menjadi kendala adalah biaya tenaga kerja dan teknologi yang menyebabkan petani enggan untuk mengelola lahan yang dimiliki oleh pemilik lahan. Hal tersebut mengakibatkan turunnya tingkat produksi sehingga pemilik lahan mau tidak mau mengelola sendiri lahan pertaniannya dengan menyewa petani penggarap yang lain. Sebagaimana yang disampaikan oleh Muhajirin dkk, (2014) yang menyatakan bahwa faktor produksi khususnya tenaga kerja tidak berpengaruh secara signifikan terhadap produksi pertanian. Hal tersebut dikarenakan faktor tenaga kerja dalam produksi usaha tani merupakan faktor utama. Sehingga, semakin luas lahan yang dikelola semakin banyak pula tenaga kerja yang dibutuhkan.

Terakhir, $\mathrm{T}$ hitung untuk $\mathrm{X} 4$ adalah sebesar $-2,680$ dengan tingkat signifikansi sebesar 0,008 yang berarti Transparansi secara parsial atau sendirisendiri memiliki pengaruh yang signifikan terhadap pemilihan model bagi hasil pertanian di Karasidenan Madiun. Berarti hipotesis yang diajukan diterima. Transparansi merupakan hal yang paling utama dalam kontrak perjanjian bagi hasil pertanian, besaran bagi hasil yang diterima oleh petani peggarap dan pemilik lahan haruslah transparan, begitupula transparansi atas lahan yang dimiliki oleh pemilik lahan, luasnya, kualitasnya, dan termasuk beban biaya penggarapan. Sehingga, jika tidak terjadi kesusuaian informasi maka hal tersebut dapat merugikan salah satu pihak, termasuk perubahan beban biaya penglohan lahan pertanian pada saat penggarapan lahan sedang berlangsung. Hal tersebut lah yang menyebabkan pengaruh transparansi yang signifikan menunjukan koefisien yang negatif. Sebagaimana yang diungkapkan oleh Wahyuni (2013) bahwa transparansi antara petani penggarap dan pemilik lahan kurang diperhatikan sehingga pengeluaran biaya pengelolaan pertanian perlu dikaji ulang.

\section{Kesimpulan}

Berdasarkan hasil analisis dan pembahasan penelitian ini menemukan bahwa, secara bersama-sama variabel sosial ekonomi, religiusitas, produksi dan transparansi berpengaruh secara signifikan terhadap pemilihan model bagi hasil pertanian di Karesidenan Madiun yang artinya hipotesis yang diajukan diterima. Sementara itu, secara parsial atau sendiri-sendiri variabel transparansi tidak memiliki pengaruh terhadap pemilihan model bagi hasil pertanian di Karesidenan Madiun. Sedangkan variabel sosial ekonomi, produksi dan religiusitas berpengaruh secara signifikan terhadap model pemilihan bagi hasil pertanian.

Berdasarkan analisis faktor religiustas secara parsial atau sendiri-sendiri, penelitian ini menemukan bahwa model bagi hasil Islam di Karesidenan Madiun belum menerapkan praktik bagi hasil pertanian Islam seperti Muzara'ah, Musaqah ataupun Mukhabarah. Hal tersebut dikarenakan petani lebih memilih praktik bagi hasil yang sudah eksis di masyarakat atau bagi hasil adat. 


\section{Daftar Pustaka}

Abdulsyani. 2007. Sosiologi, Skematika, Teori, Dan Terapan, Jakarta: PT. Bumi Aksara.

Asmani, Jamal Ma'mur. 2012. Tips Aplikasi Manajemen Sekolah, Yogyakarta: DIVA Press.

Asnawi, Haris Faulidi. 2005. Sistem Muzara'ah dalam Ekonomi Islam. Jurnal Millah, IV(2).

Braverman, A., \& Srinivasan, T. N. 1981. Credit and sharecropping in agrarian societies. Journal of Development Economics, 9(3), 289-312.

Burhanuddin. 2010. Aspek Hukum Lembaga Keuangan Syariah, Yogyakarta: Graha Ilmu.

Darhum, dan Logawali, Thamrin. 2016. Penerapan Sistem Muzara'ah dalam Meningkatkan Kesejahteraan Masyarakat di Kelurahan Palampang Kecamatan Rilau Ale Kabupaten Bulukumba. Jurnal Iqtisaduna, 2(2).

Daryanto. 2003. Dasar-dasar Teknik Mesin, Jakarta: PT. Bhineka Cipta Jakarta.

Dede, Moh \& Sahidin Banyu Sewu, Rizal \& Yutika, Meisa \& Ramadhan, Fatich. 2016. Analisis Potensi Perekonomian Sektor Pertanian, Kehutanan, dan Perikanan Serta Pertambangan dan Penggalian di Pantura Jawa Barat. Prosiding Seminar Epicentrum 5.5 Bandung.

El-Menouar, Yasemin. 2014. The Five Dimensions of Muslim Religiosity Results of an Empirical Study, Journal of Method, Data, Analyses, 8.

Erviana, E. 2005. Pelaksanaan Perjanjian Bagi Hasil Tanah Pertanian Di Kabupaten Ogan Komering Ilir Propinsi Sumatera Selatan (Doctoral Dissertation, Program Pascasarjana Universitas Diponegoro).

Iswahyudi, Aries, Iwan Triyuwono, M. Achsin. 2016. Hubungan Pemahaman Akuntabilitas, Transparansi, Partisipasi, Value for Money dan Good Governance (Studi Empiris pada SKPD di Kabupaten Lumajang). Jurnal Ilmiah Akuntansi, 1(2).

Karim, Adiwarman A., 2004. Bank Islam Analisis Fiqih dan Keuangan, Jakarta: PT. Raja Grapindo Persada.

Mahananto, Salyo Sutrisno, Candra F. Ananda. 2009. Faktor-Faktor yang Mempengaruhi Produksi Padi Studi Kasus di Kecamatan Nogosari, Boyolali, Jawa Tengah, Jurnal Wacana, 12(1).

Marbun. 2003. Kamus Manajemen. Jakarta: Pustaka Sinar Harapan.

Mardiasmo. 2004. Akuntansi Sektor Publik, Yogyakarta: Penerbit Andi.

Moleong, Lexy J. 1997. Metodologi Penelitian Kualitatif, Bandung: Penerbit PT Remaja Rosdakarya.

Muhajirin, M., \& Elwamendri, E. 2014. Analisis faktor-faktor yang mempengaruhi produksi usahatani padi sawah di Kecamatan Batang Asai Kabupaten Sarolangun. Jurnal Sosio Ekonomika Bisnis, 17(1).

Nashori, Fuad \& Mucharram, R.D., 2002. Mengembangkan Kreativitas dalam Prespekti Psikologi Islam, Yogyakarta: Menara Kudus.

Nashori, Fuad. 2002. Agenda Psikologi Islami, Yogyakarta: Pustaka Pelajar.

Ngadiyono. 1998. Pengantar Ilmu Pendidikan, Bandung: Alumni.

Nugraha, Jefri Putri. 2016. Sistem Muzara'ah Sebagai Alternatif Pembiayaan Pertanian di Indonesia, Iqtishodia: Jurnal Ekonomi Syari'ah. 1(2). 
Nurmadany, Rizka. 2016. Pelaksanaan Perjanjian Bagi Hasil Tanah Pertanian Antara Pemilik Tanah dan Penggarap di Kabupaten Sleman. Jurnal Hukum Atma Jaya Yogyakarta, Desember.

Piaw, Chua Yan. 2006. Buku 2 Asas Statistik Penelitian, Kuala Lumpur: McGraw Hill Education.

Priyadi, Unggul, dan Shidiqie, Jannahar Saddam. 2015. Pelaksanaan Perjanjian Bagi Hasil Pertanian Lahan Sawah Studi di Kecamatan Gamping, Kabupaten Sleman, Yogyakarta. Millah, XV(1).

Rondhi, M., \& Adi, A. H. 2018. The Effects of Land Ownership on Production, Labor Allocation, and Rice Farming Efficiency. AGRARIS: Journal of Agribusiness and Rural Development Research, 4(2), 101-110.

Santoso, Urip. 2014. Kepastian Hukum Wakaf Tanah Hak Milik. Jurnal Perspektif, 19(2).

Sevilla, Consuelo G., 1984. Research Methods, Quezon City: Rex Printing Co. Inc.

Silvira, Hasyim, Hasman, Fauzia, Lily. 2013. Analisis Faktor-Faktor yang Mempengaruhi Produksi Padi Sawah (Studi Kasus: Desa Medang, Kecamatan Medang Deras, Kabupaten Batu Bara). Journal on Social Economic of Agriculture and Agribusiness. 2 (4).

Soekanto, Soerjono. 1986. Intisari Hukum Perikatan Adat, Jakarta: Ghalia Indonesia.

Sugiyono. 2007. Metode Penelitian Kuantitatif Kualitatif dan $R \& D$. Bandung: Penerbit Alfabeta.

Sugiyono. 2014. Metode Penelitian Bisnis, Cet. 18, Bandung: Penerbit Alfabeta.

Suhendi, Hendi. 2008. Fiqh Muamalah, Jakarta: Raja Grafindo Persada.

Sukirno, Sadono. 2008. Mikroekonomi: Sebuah Pengantar, Jakarta: PT. Raja Grafindo Persada.

Syafi'i, Imam Abi Abdillah Muhammad bin Idris. 1961. Al Umm, J.7, Mesir: Darul Fikri.

Talundu, Jein Feybe. 2015. Kondisi Sosial Ekonomi Masyarakat Petani Sawah di Desa Tanah Harapan Kecamatan Palolo Kabupaten Sigi. E-Journal GeoTadulako UNTAD, 3 (2). 1-13.

Torar, D. J. 2017. Faktor Sosial Ekonomi dan Budaya yang Mempengaruhi Usahatani Kelapa di Kabupaten Kepulauan Talaud. Buletin Palma, (36), 4861.

Wahyuni, Andi Sri., 2013. Penyesuaian Konsep Bagi Hasil Adat-Syariah. Jurnal Akuntansi Multiparadigma, 4(3).

Badan Pusat Statistik Jawa Timur, (2018), Provinsi Jawa Timur dalam Angka 2018, Surabaya: BPS Jawa Timur.

Badan Pusat Statistik Jawa Timur, (2018), Hasil Survei Pertanian Antar Sensus (SUTAS) 2018 Provinsi Jawa Timur, Surabaya: BPS Jawa Timur.

Badan Pusat Statistik Indonesia, (2018), Luas Panen dan Produksi Beras di Indonesia 2018; Hasil Kegiatan Pendataan Statistik Pertanian Tanaman Pangan Terintegrasi dengan Metode Kerangka Sampel Area, Jakarta: BPS. 